ærinde, men at det bestemt ikke er den fulde sandhed om Grundtvigs ejendommelige brug af billedsprog. "Grundtvig ikke alene skriver symbolistisk-ekspressionistisk, men ser også sig selv og sin samlede virksomhed som et symbol«, skriver Fl. Lundgreen-Nielsen i »Det handlende ord «, II, side 888. "Endnu i en tid, der var langt mere vejende, målende og tællende...måtte Freud og Jung ty til billeder og modeller for at anskueliggøre deres opfattelse af den usynlige åndelige virkelighed i menneskets indre« (sst. s.887).

Betænkeligheder og indvendinger til trods er det en fornøjelse at læse en bog, der behandler det moderne Europas situation i et åndshistorisk perspektiv. Hvis ikke man vidste det før, så ved man efter læsning af Engbergs bog, at der er langt større kræfter på spil i dagens Europa, end dem der udtrykkes i politiske og markedsøkonomiske termer. At Grundtvig har anet disse kræfters tilstedeværelse som konstante faktorer i Europas historie, og at han derfor stadig kan have noget væsentligt at sige om forskellen på folkelighed og nationalisme, patriotisme og racisme, folkelig vækkelse og politisk opinionsdannelse, det er man ikke i tvivl om efter læsning af denne bog.

\title{
Nornesalen - forskning i spændingsfeltet mellem akademisk tradition og folkelig aktualitet
}

\author{
Af Kim Arne Pedersen
}

Nornesalen. Forskning 1992-1993. Ringe 1993. Lilian Zфllner (red.): Almen Dannelse Folkelig Dannelse Folkelig Livsoplysning. Vejle 1993.

Det er med en vis forventning, man sætter sig til at læse de to bøger, der her skal anmeldes. Forventningerne skyldes, at der er tale om henholdsvis det første årsskrift og den første egentlige udgivelse fra en ny og utraditionel videnskabelig institution, det i 1992 indviede "Nornesalen Forskningscenter for folkelig livsoplysning «. Dette forskningscenter hører under Kulturministeriet og er knyttet til Biblioteket for det Folkelige arbejde, som i 1985 oprettedes af repræsentanter for Den frie lærerskole, Foreningen for folkehøjskoler i Danmark, Dansk Friskoleforening, Foreningen af Frie Ungdomsog Efterskoler og De danske Gymnastik- og ungdomsforeninger. Såvel bibliotek som forskningscenter er beliggende på Den frie Lærerskole i Ollerup. En drivende kraft $\mathrm{i}$ arbejdet med etableringen af det nævnte bibliotek, der fungerer som landsarkiv for de folkelige bevægelser, var afdøde fhv. fri- 
skolelærer Carlo Larsen, der ikke blot formåede at forene sine visionære egenskaber med en praktisk igangsættende evne, men også selv bidrog til Nornesalens forskning gennem et projekt om det idemæssige grundlag for de nye friskoler, der opstod i 1970-erne. Også forstander Ove Korsgaard inspirerede og bidrog til forskningscenterets oprettelse, og i centerets bestyrelse sidder repræsentanter for friskolerne og højskolerne i Danmark. Siden oprettelsen har forskningscenteret været ledet af Lilian Zøllner, hvis baggrund er mangeårig forskning på Danmarks lærerhøjskole, en forskning, der i 1992 resulterede i Ph.D.-graden for en afhandling om medicinsk etik. Lilian Zøllner spænder meget vidt i sit arbejde, idet hun også arbejder med ungdomsholdninger samt med de grundtvigske skoletankers virkningshistorie i udlandet. I Nornesalens forskningsplaner indgår en bogrække, der skal kortlægge de grundtvigske skoletankers indflydelse i samtlige verdensdele. Her vil Lilian Zøllners undersøgelse af skoletankernes betydning i Asien blive udgivet i nær fremtid. Den $\emptyset$ vrige forskning på Nornesalen varetages af stipendiater, der ansættes i perioder fra en måneds og op til et års varighed.

Der er altså tale om et forskningscenter, der ligger udenfor universiteterne, der almindeligvis udgør rammerne for videnskabeligt arbejde i Danmark. Ydermere er der tale om forskning, der, - som det fremgår af centerets navn - ligger i forlængelse af de grundtvigsk inspirerede folkelige bevægelser i Danmark, og dermed også af Grundtvigs tanker. Ved Nornesalens indvielse blev det sagt, at centeret bidrog til en delvis realisering af Grundtvigs drøm om universitetet i Göteborg. Man må på grundlag af disse forhold - og især førstnævnte - formode, at Nornesalen forsøger at leve op til de grundtvigske videnskabsidealer. En grundtvigsk videnskab skal være livsnær på en anderledes måde, end det er tilfældet med, hvad man almindeligvis opfatter som universitetets stuelærde og distancerende analyser og tolkninger. Denne livsnærhed bør komme til udtryk både i form og indhold, størrelser, der i et grundtvigsk univers, hvor sproget udtrykker ånden, ikke kan skilles ad. Uden at forfalde til gentagelse af de grundtvigske formler kan det slås fast, at den grundtvigske videnskab bør kunne formidle mellem læg og lærd i den forstand, at forskningsresultaterne er alment forståelige, ligesom disses indhold har direkte interesse for det folkelige, for samfundsborgernes fælles identitet og samliv. Spørgsmålet bliver så, om den videnskab, Nornesalen præsenterer, adskiller sig fra den etablerede forskning i Danmark, og i videre forstand, om den etablerede forskning, som det ofte siges, adskiller sig så markant fra de grundtvigske videnskabsidealer.

I henseende til spørgsmålet om forskningens form er det utvivlsomt først og fremmest i Nornesalens første udgivelse om folkelig dannelse, eventuelle nye veje og formidlingsstrategier vil komme til udtryk. Et blik på bogens disposition viser, at bogen fremstår som et samleværk med bidrag af en 
række højst forskellige mennesker. Her er da valgt den form, der langtfra er ukendt i den akademiske verden, nemlig at lade ethvert hovedindlæg blive fulgt op af en kritisk kommentar. Idet her som før nævnt skal tages forbehold overfor en brug af Grundtvig, der ikke reflekterer over effekten af en blot gentagelse af Grundtvigs sprog i dag, skal det samtidig siges, at denne form også imødekommer den grundtvigske pædagogiks fundering i samtalen, i dialogen mellem lærer og elev, forelæser og tilhører. Når det da gælder sproget, ville det være på sin plads at vurdere hvert indlæg for sig med henblik på at bedømme, hvorvidt der er tale om en formidling mellem læg og lærd, der giver den livsoplysningsspørgende lægmand mulighed for at læse, forstå og indoptage en række tolkninger og vurderinger. Her gør der sig naturligt nok store forskelle gældende. Vanskeligst tilgængelig er utvivlsomt Hans Jørgen Schanz's analyse af modernitetens nyvundne modenhed. Mere letlæselige er eksempelvis K.E. Bugges og Lilian Zøllners indlæg. Som helhed må de forskellige indlægs form vurderes positivt, - der er virkelig tale om, at et videnskabeligt værk lader sig benytte af uddannelsesinstitutionerne og generelt $\mathrm{i}$ alle kredse, hvor »uddannelsespolitiske spørgsmål behandles « (s. 7). Samtidig betyder det ikke, at der gives køb i forbindelse med værkets videnskabelighed: selv om der er tale om mindre indlæg, er de udformet, så de kan benyttes i forskningsmæssig sammenhæng.

Til denne ydre, formelle side af bogen svarer den indholdsmæssige side. Samtlige bogens indlæg behandler emner, der kan relateres til Grundtvigs forfatterskab, uden at de derfor alle kan betegnes som Grundtvig-forskning eller forskning i Grundtvigs virkningshistorie. For en anmeldelse i »Grundtvig Studier « er det naturligvis de direkte Grundtvig-relaterede tekster, der påkalder sig størst interesse. Værket indledes med Lilian Zøllers præsentation af de i bogtitlen nævnte begreber, hvorefter K.E. Bugge behandler Grundtvigs syn på folkelig dannelse. Gennem Bugges og Korsgaards diskussion fremkommer nogle væsentlige tilløb til en præcisering af Grundtvigs forståelse af det universelle eller det almentmenneskelige $i$ dettes forhold til den nationale identitet, idet man dog her kunne have ønsket sig, at den implicitte skabelsesteologiske dimension, Bugge påviser i Grundtvigs bestemmelse af det almentmenneskelige, var blevet udbygget med en redegørelse for forholdet mellem menneskeligt og kristeligt. Hans Hauge sammenholder Grundtvig og Bloom og mener i den forbindelse at kunne henholde sig til, at Grundtvig i skriftet »Statsmæssig Oplysning « gør universitetet til »en ren Maria-Skole« (s. 89), dvs. en skole, fra hvilken den praktiske embedsmandsuddannelse er skilt ud. Med denne ene henvisning gør Hauge det for let for sig selv, her kunne man have ønsket en grundigere og bredere behandling af Grundtvigs videnskabssyn, hvor også Göteborgtankerne var inddraget. Kjeld Fredens knytter under inddragelse af Grundt- 
vigs tænkning forbindelsen mellem kunst og videnskab. Der er tale om en række spændende og frugtbare overvejelser, der i endnu højere grad, end det er tilfældet, kunne have været relateret til Grundtvigs erkendelsesteori, der netop udmærker sig ved at sammenknytte kunst/billeddannelse, følelse og forstand/fornuft i en treleddet bevægelse. Niels Buur Hansens kommentar til Kjeld Fredens indlæg griber skarpsindigt fat i den placering, kunsten gives i det moderne. Buur Hansen inddrager Grundtvigs holdning til det æstetiske, men kunne her have gravet et spadestik dybere ved at behandle de refleksioner over æstetikkens grundbegreber, man finder i Grundtvigs filosofiske tidsskrift Danne-Virke. Buur Hansens korrekturlæser burde i $\varnothing v$ vrigt have rettet hans omtale af biskop Martens til biskop Martensen, en fejl, der skurrer $\mathrm{i}$ en ellers smuk udgivelse. Som helhed fremstår bogen som en spændende udgivelse, der med sine mange stemmer fra universitetet og det praktiske liv muliggør den relatering af forskningen til folkelivet, som var Grundtvigs ideal.

Nornesalens årsskrift fremstår ligeledes som en imponerende publikation, hvor det smukke layout allerede fra begyndelsen giver læseren lyst til at se nærmere på de forskellige bidrag. Efter en grundig fremstilling af centerets tilblivelseshistorie følger en række artikler, der præsenterer den igangværende forskning. Artiklernes form muliggør, at de kan læses med udbytte af både læg og lærd. Sproget er klart og flydende, og der er til de fleste bidrag et godt noteapparat eller en litteraturliste. I henseende til formen kommer årsskriftet således de grundtvigske videnskabsidealer i møde, og at der også i henseende til indholdet er tale om forskning, der udspringer af og tager sigte på livet, som det leves i skole og samfund, bliver hurtigt læseren klart. Carlo Larsens undersøgelse satte eksempelvis nærværende anmelder i gang med refleksioner over den folkelige bevidstgørelses vilkår i et samfund, der som vort præges af en stadig større afstand mellem befolkning og beslutningstagere og af offentlige institutioners monopolisering af undervisningen. Lilian Zøllners artikel imponerer gennem sin omhyggelige kortlægning af de forskellige typer, der kan opstilles gennem en unders $\emptyset$ gelse af unges overvejelser over meningen med livet. I artiklen henvises løbende til tænkere som eksempelvis Erich Fromm og Victor Frankl, men også teologen Paul Tillich benyttes, omend hans tænkning drejes i en retning, hvor Tillichs kristne udgangspunkt fortones. Selv om artiklens afsluttende problematisering af et traditionelt kristent begrebsapparats relevans i det moderne samfund mærkværdigvis ikke nævner eller tager hensyn til det store teologiske formidlingsarbejde, der finder sted i disse år, er det alligevel bemærkelsesværdigt, at Nornesalens forskning ikke blot begrænser sig til undervisningsspørgsmål, men også inddrager områder, der forbinder religionsvidenskab, teologi, filosofi og psykologi med aktuelle analyser af nutidsmenneskers tanker og holdninger. For Grundtvig-interesserede påkalder 
særlig Anette Bøtter-Jensens, Lilian Z $ø$ llners og Tine Damsholts artikler sig interesse, samtidig med, at også de øvrige artikler omfatter emner, der står i forbindelse med Grundtvigs virkningshistorie. Bøtter-Jensen beskæftiger sig med Grundtvigs dannelsesbegreb i en større sammenhæng, Lilian Zøllner arbejder med Grundtvigs skoletankers virkningshistorie i Japan, og Tine Damsholt tager med en undersøgelse af Grundtvigs demokratibegreb et underbehandlet emne i Grundtvigforskningen op. For kendere af Grundtvigs forfatterskab er der grund til at standse op ved netop denne artikel, Grundtvigs tanker om forholdet mellem den fri folkestemme, der formulerer det fælles bedste, og kongen eller regeringen, der med fri magt udfører denne, sættes ind i en idehistorisk sammenhæng, ligesom det lykkes Tine Damsholt at påvise, at Grundtvig ikke, som ofte antaget, foretager en politisk kovending i 1848 i forbindelse med folkestyrets indførelse. I nær fremtid udgiver Nornesalen den bog, Tine Damsholt præsenterer i årsskriftet, og Grundtvigforskningen vil derigennem blive tilført et væsentligt arbejde om et vigtigt emne.

Den afsluttende liste over Nornesalens forskningsprojekter og formidlingsbestræbelser viser, hvorledes den nyetablerede forskningsinstitution (der er af begrænset størrelse sammenlignet med de gamle etablerede institutioner) gennem en dynamisk pionerholdning er i stand til at sætte en lang række projekter i gang, ligesom der i de kommende år vil udkomme indtil flere bogudgivelser årligt, spændende fra historisk forskning med en aktuel dimension til studier i nutidige problemstillinger.

Gennem et samarbejde med Linköping Universitet i Sverige, Norsk Voksenpedagogisk Forskningsinstitut, Danmarks Lærerhøjskole, Københavns Universitet, Odense Universitet og Center for Grundtvig-studier, Aarhus Universitet lykkes det Nornesalen at knytte forbindelser mellem den akademiske verden og den folkelige virkelighed, hvor forskningen skal bevise sin brugbarhed og aktualitet. Der er således virkelig tale om, at Nornesalen kan ses i forlængelse af de videnskabsidealer, der har rødder i Grundtvigs forfatterskab. Der er grund til at ønske Nornesalen til lykke med etableringen, forskningen og formidlingen. De kommende år vil utvivlsomt vise, at Nornesalen formår at videreføre denne strålende begyndelse. 